Available online on 15.12.2019 at http://jddtonline.info
Open Access to Pharmaceutical and Medical Research
unrestricted non-commercial use, provided the original work is properly cited

Open@ Access

Research Article

\title{
Method Development and Validation for Simultaneous Estimation of Benidipine Hydrochloride and Metoprolol Succinate in Tablet
}

\author{
Patel Advaita ${ }^{1 *}$, Patel Deepa . ${ }^{2}$, Patel Dhaval ${ }^{1}$, Sheth Avani ${ }^{1}$, Shah Utsav J. ${ }^{3}$ \\ ${ }^{1}$ Associate Professor, Department of Pharmaceutical Chemistry, SAL Institute of Pharmacy, Ahmedabad, India \\ 2 Professor, Department of Pharmaceutical Chemistry, Kalol Institute of Pharmacy, Ahmedabad, India \\ ${ }^{3}$ Student, Kalol Institute of Pharmacy, Ahmedabad, India
}

\begin{abstract}
Present work focusing in developing and validating a new high performance liquid chromatography method for estimation of Meto prolol Succinate and Benidipine Hydrochloride in their combine tablet dosage form. The method was performed on Shimadzu LC-20AT instrument using $\mathrm{C}_{18}(250 \mathrm{~mm}$ x $4.6 \mathrm{~mm}, 5 \mu \mathrm{m}$ ) Hypersil BDS Column and Potassium Dihydrogen Phosphate Buffer (pH 4.0): Methanol (65: 35\% v/v) as mobile phase at ambient temperature. Detection was carried out at $269 \mathrm{~nm}$. Concentration range 4-12 $\mu \mathrm{g} / \mathrm{ml}$ for Benidipine Hydrochloride and $25-75 \mu \mathrm{g} / \mathrm{ml}$ for Metoprolol Succinate. The Percentage recovery of Benidipine Hydrochloride and Metoprrolol succinate was found to be 99.59\% and 99.39 respectively. Correlation coefficient for Metoprolol succinate and Benidipine Hydrochloride was found 0.9995 and 0.9997 respectively. The Rt values for Metoprolol succinate and Benidipine Hydrochloride were found to be 3.4 and 5.9 min respectively. The method was validated according to the guidelines of International Conference on Harmonisation (ICH) and was successfully employed in the estimation of commercial formulations.
\end{abstract}

Keywords: Metoprolol Succinate, Benidipine Hydrochoride, HPLC, Mobile Phase,

Article Info: Received 12 Sep 2019; $\quad$ Review Completed 06 Nov 2019; $\quad$ Accepted 19 Nov 2019; Available online 15 Dec 2019

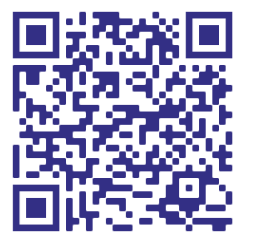

Cite this article as:

Patel A, Patel D, Patel D, Sheth A, Shah UJ, Method Development and Validation for Simultaneous Estimation of Benidipine Hydrochloride and Metoprolol Succinate in Tablet, Journal of Drug Delivery and Therapeutics. 2019; 9(6s):28-33 http://dx.doi.org/10.22270/jddt.v9i6-s.3692

Patel Advaita, Associate Professor, Department of Pharmaceutical Chemistry, SAL Institute of Pharmacy, Ahmedabad, India

\section{INTRODUCTION}

Metoprolol succinate is Beta-Blocker class of drug and chemically it is bis 1-[4-(2-methoxyethyl) phenoxy]-3(propan-2-yl) amino] propan-2-ol ; butanedioic acid. 1,2,3 Benidipine hydrochloride is a long acting dihydropyridine $\mathrm{Ca}++$ channel blocker and chemically it is 05-methyl 03[(3R)-1-(phenylmethyl)piperidin-3-yl] 2,6-dimethyl-4-(3nitrophenyl)-1,4-dihydropyridine-3,5-dicarboxylate, hydrochloride. 1,2,4 Structure of Metoprolol succinate is illustrated in figure I. Structure of Benidipine Hydrochloride is illustrated in figure II.

So far, to our present knowledge a literature survey revealed that various methods are reported for the analysis of individual drug and in combination with other drugs but any RP- HPLC method is not reported for these two drugs in combined dosage form.5-27 Therefore, it was thought worthwhile to Develop and Validate RP-HPLC methods for analysis of Benidipine Hydrochloride and Metoprolol Succinate in its Pharmaceutical Dosage Form.

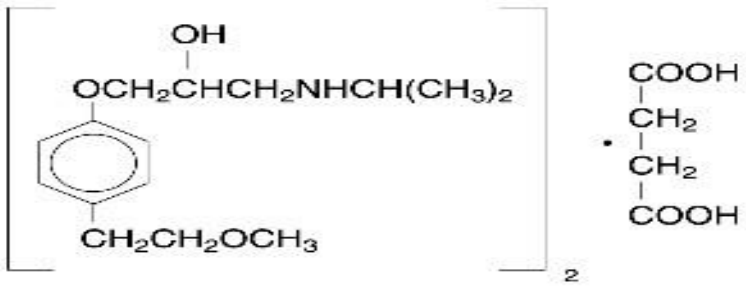

Figure I : Structure of Metoprolol Succinate<smiles>COC(=O)C1=C(C)NC(C)=C(C(=O)O[C@H]2CCCN(Cc3ccccc3)C2)C1c1cccc([N+](=O)[O-])c1</smiles>

. $\mathrm{HCl}$ 


\section{MATERIALS AND METHODS}

Reagents and Chemicals : Metoprolol succinate was received as a gift sample from Intas Pharmaceuticals Pvt. Ltd , Ahmedabad and Benidipine Hydrochoride was received as a gift sample from Prayosha Healthcare Pvt. Ltd, Ankleshwar. All chemicals and reagents used were a HPLC grade and purchased from Merck specialties Pvt., Ltd., Mumbai. Combined Tablet Formulation (Benipack- M) was procured from Local market.

\section{Preparation of mobile phase:}

Mobile phase was prepared by mixing $65 \mathrm{ml}$ of Potassium Dihydrogen Phosphate Buffer $(\mathrm{pH} 4.0)$ and $35 \mathrm{ml}$ of methanol and degas in ultrasonic water bath for 15 minutes. Filter through $0.2 \mu$ filter under vacuum filtration before injection.

\section{Chromatographic Conditions:}

- Column : C18 (250 mm x 4.6 mm, $5 \mu \mathrm{m}$ ) Hypersil BDS

- Mode of Elution : Isocratic

- Mobile phase : Potassium Dihydrogen Phosphate Buffer (pH 4.0): Methanol (65: 35\% v/v)

- $\quad$ Detection Wavelength : $269 \mathrm{~nm}$

- Injection volume : $20 \mu \mathrm{l}$

- Flow rate : $1.0 \mathrm{ml} / \mathrm{min}$

- Column Temperature: $25^{\circ} \mathrm{C}$

- $\quad$ Run time : 07 minutes

Preparation of Standard stock solution Metoprolol Succinate $(50 \mu \mathrm{g} / \mathrm{ml})$ and Benidipine Hydrochloride $(8 \mu \mathrm{g} / \mathrm{ml})$

Accurately weigh and transfer $50 \mathrm{mg}$ of weighed quantity of Metoprolol Succinate and $8 \mathrm{mg}$ of Benidipine Hydrochloride and dilute it up to $100 \mathrm{ml}$ with Methanol. Further from above solution take $1 \mathrm{ml}$ and make the final volume up to $10 \mathrm{ml}$ with the use of Methanol to produce $50 \mu \mathrm{g} / \mathrm{ml}$ of Metoprolol Succinate and $8 \mu \mathrm{g} / \mathrm{ml}$ of Benidipine Hydrochloride .

Preparation of Standard solution of binary mixtures of Metoprolol Succinate $(50 \mu \mathrm{g} / \mathrm{mL})$ and Benidipine $\mathrm{HCl}(8$ $\mu \mathrm{g} / \mathrm{mL}$ )

Form standard stock solution take $1 \mathrm{ml}$ from the Metoprolol Succinate Stock solution and $1 \mathrm{ml}$ from Benidipine Hydrochloride Stock solution respectively and transferred to $10 \mathrm{ml}$ volumetric flask and volume was made up to the mark by mobile phase.

\section{Selection of Wavelength:}

Metoprolol Succinate $(50 \mu \mathrm{g} / \mathrm{ml})$ and Benidipine Hydrochloride $(8 \mu \mathrm{g} / \mathrm{ml})$ were prepared in Methanol as per above mentioned procedure. After that these drug solutions were scanned in UV region of $200-400 \mathrm{~nm}$ and overlay spectrums were recorded. The observed UV Spectra is mentioned in figure no. III. From the spectra $269 \mathrm{~nm}$ was selected as a wavelength of detection.

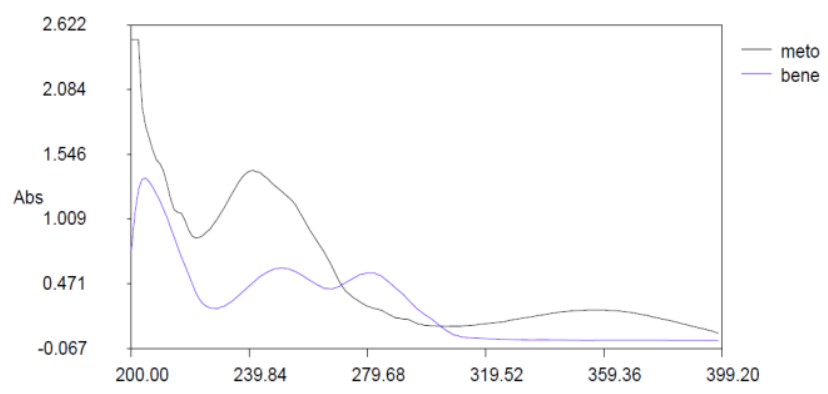

Figure III : Overlay Spectra of Metoprolol Succinate and Benidipine Hydrochloride

Preparation of Calibration Curve : Calibration curves were plotted over a concentration range of $4-12 \mu \mathrm{g} / \mathrm{ml}$ for Benidipine Hydrochloride and 25-75 $\mu \mathrm{g} / \mathrm{ml}$ for Metoprolol Succinate. Accurately measured standard stock solution Volume as 5,7.5,10,12.5,15 ml solutions were pipette out from the Stock solution of Metoprolol Succinate $(500 \mu \mathrm{g} / \mathrm{ml})$ and Benidipine Hydrochloride $(80 \mu \mathrm{g} / \mathrm{ml})$ and transfer to $100 \mathrm{ml}$ volumetric flask and make up with mobile phase to obtain 25,37.5,50,62.5 and $75 \mu \mathrm{g} / \mathrm{ml}$, and 4,6,8,10 and $12 \mu \mathrm{g} / \mathrm{ml}$ for Metoprolol Succinate and Benidipine Hydrochloride respectively.

Preparation of Sample Stock Solution (Benidipine HCl 80 $\mu \mathrm{g} / \mathrm{mL}$, Metoprolol Succinate $500 \mu \mathrm{g} / \mathrm{ml}$ )

10 tablets were weighed and finely powdered. The average weight was calculated. A portion of powder equivalent to the weight of one tablet was accurately weighed and transferred to a $100 \mathrm{ml}$ volumetric flask. (8mg of Benidipine $\mathrm{HCl}$, and $50 \mathrm{mg}$ of Metoprolol Succinate). Add $60 \mathrm{ml}$ Mobile phase and Shake for $15 \mathrm{~min}$ and make up volume with Mobile phase. The solution was filtered through Whatman filter paper no. 42.

\section{RESULTS AND DISCUSSION:}

\section{Method Validation Parameters:}

The method was validated by establishing linearity, accuracy, interday and intraday precision of measurement of sample application. The limit of detection and the limit of quantification were also determined. Chromatogram of Metoprolol succinate and Benidipine Hydrochloride in active pharmaceutical ingredients is shown in figure no. IV, $\mathrm{V}$ and VI. Chromatogram of Metoprolol succinate and Benidipine Hydrochloride in Tablet dosage form is shown in figure no. VII. 


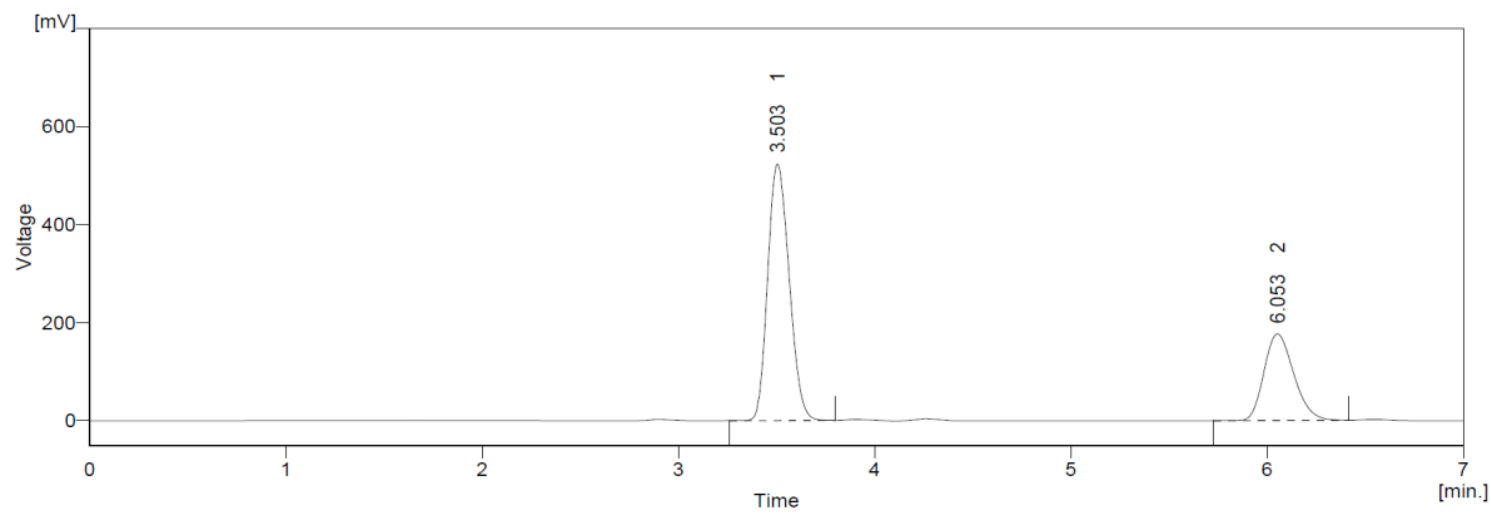

Figure IV : Chromatogram of Benidipine $\mathrm{HCl}$ and Metoprolol Succinate in standard solution.

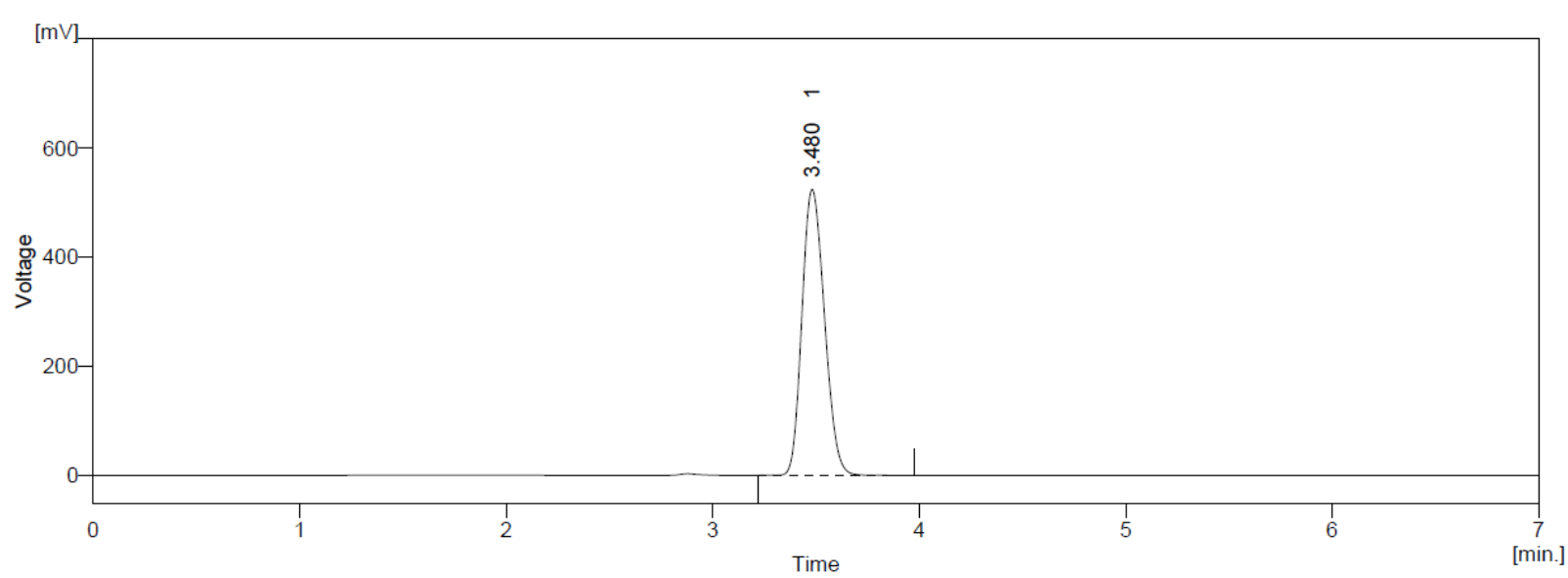

Figure V: Chromatogram of Metoprolol Succinate

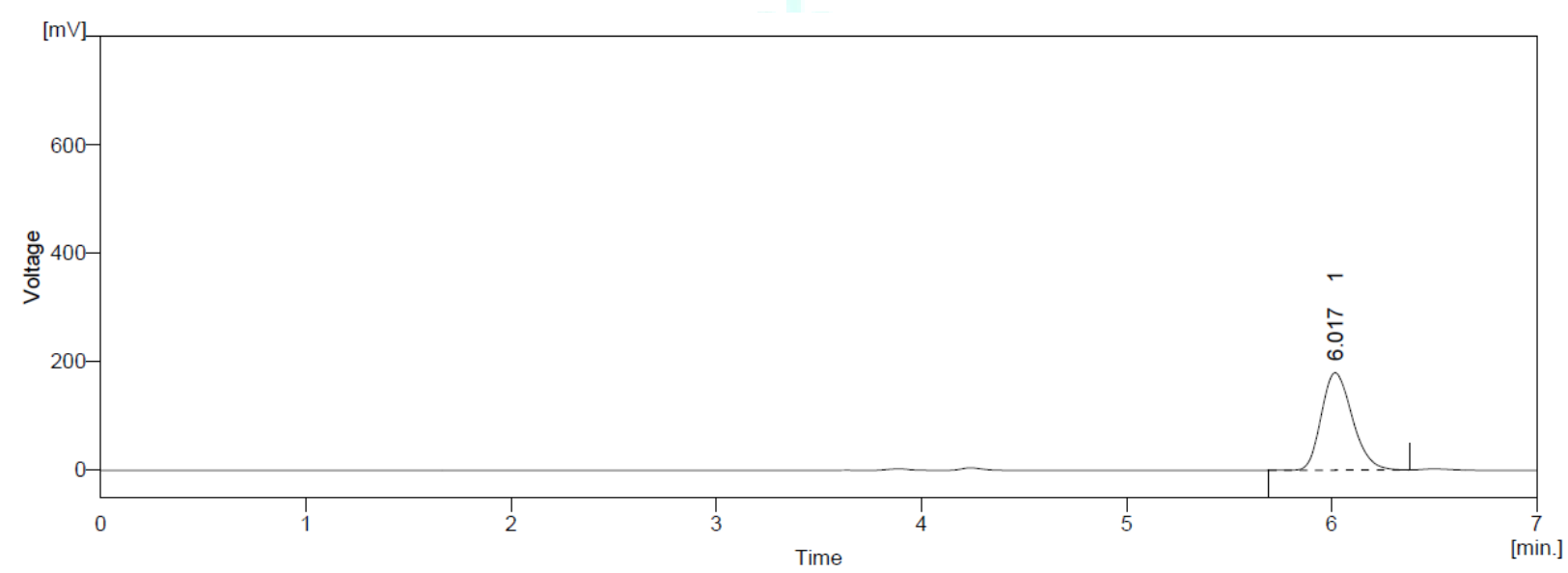

Figure VI: Chromatogram of Benidipine HCl

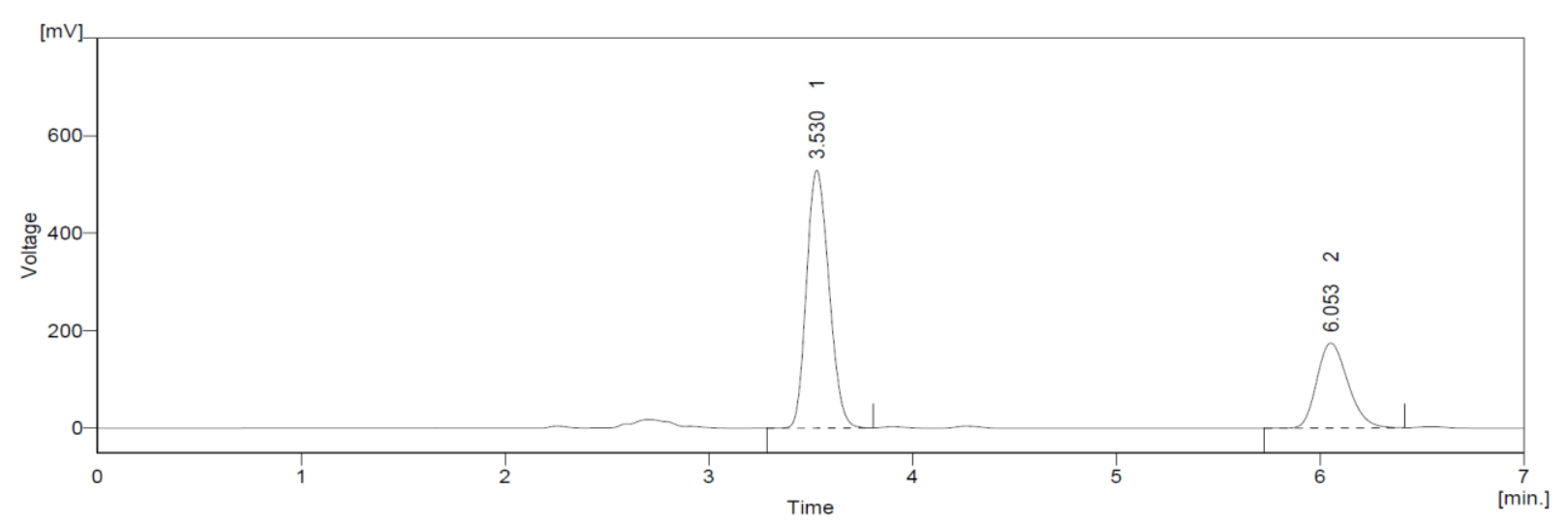

Figure VII : Chromatogram of Benidipine $\mathrm{HCl}$ and Metoprolol Succinate in sample solution. 


\section{Method Validation Parameters: 28,29}

\section{Linearity:}

Calibration curve were found to be linear in the range of 25$75 \mu \mathrm{g} / \mathrm{ml}$ of Metoprolol Succinate and 4-12 $\mu \mathrm{g} / \mathrm{ml}$ of Benidipine Hydrochloride .Five concentration points were assayed in triplicate. Both Metoprolol Succinate and Benidipine Hydrochloride showed good linearity in tested range. The regression coefficient (R2) value for Metoprolol Succinate and Benidipine Hydrochoride were found to be 0.9995 and 0.9997 respectively. Linear regression data for the calibration plots are illustrated in figure no VIII and IX respectively. Overlay chromatogram of different concentrations of mixtures of Metoprolol Succinate and Benidipine Hydrochloride is shown in figure no $\mathrm{X}$.

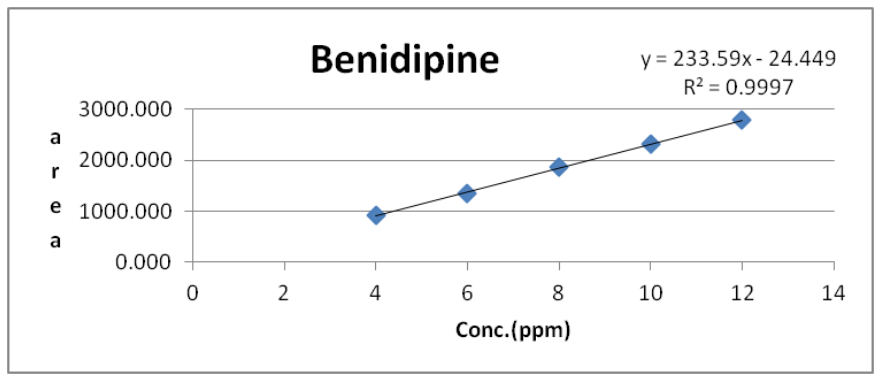

Figure VIII : Calibration Curve of Benidipine $\mathrm{HCl}(4-12 \mathrm{Mg} / \mathrm{Ml})$

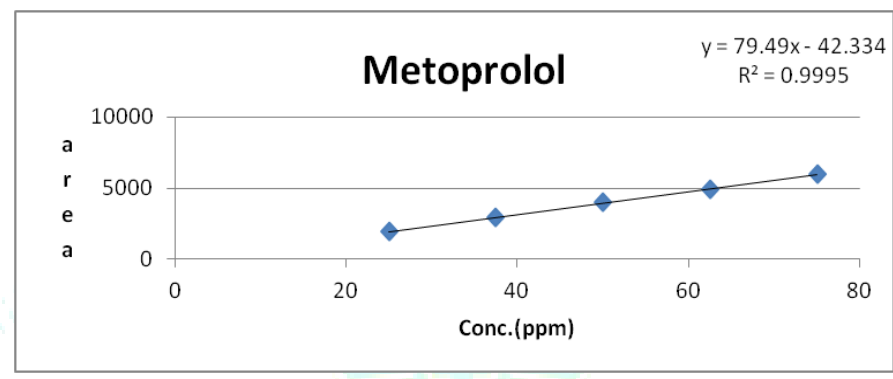

Figure IX : Calibration Curve of Metoprolol Succinate (25-75 MG/ML)

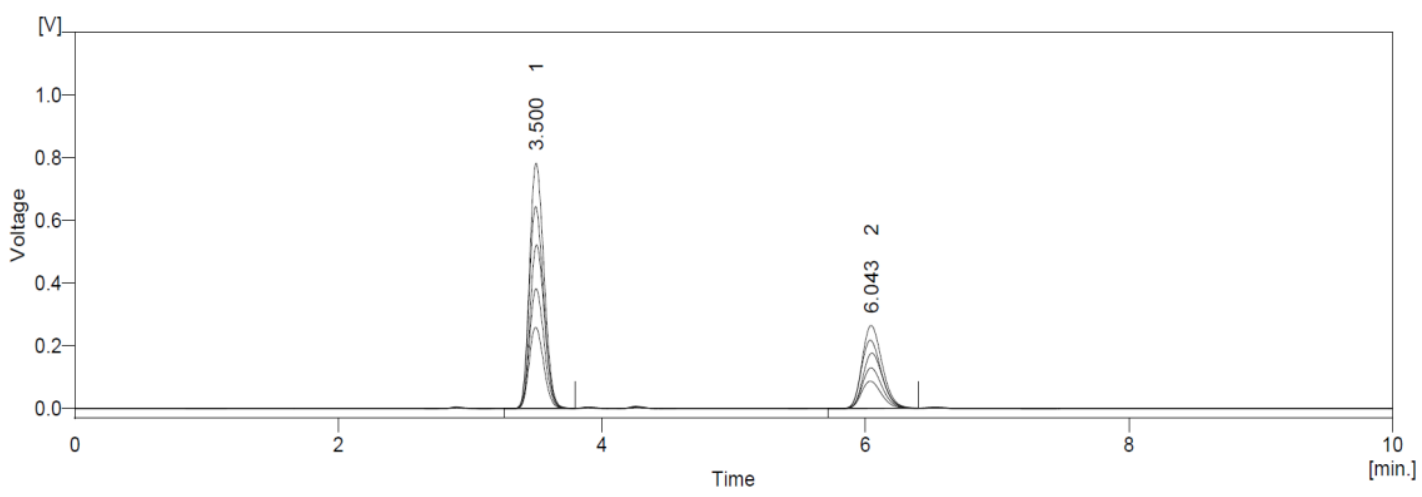

Figure X: Overlay Chromatogram of different concentrations of mixtures of Metoprolol Succinate and Benidipine Hydrochloride

Accuracy: Accuracy may often be expressed as \% Recovery by the assay of known, added amount of analyte. It is measure of the exactness of the analytical method. The recovery experiments were carried out in triplicate by spiking previously analyzed samples of the tablets ( Metoprolol succinate and Benidipine Hydrochloride ) with three different concentrations of standards at $80 \%, 100 \%$ and 120\% Metoprolol Succinate ( 20,25 $30 \mu \mathrm{g} / \mathrm{ml}$ ) and Benidipine Hydrochloride $(3.2,4,4.8 \mu \mathrm{g} / \mathrm{ml})$. The $\%$ recovery were calculated and found to be within the limit as shown in table no I.

Table I : \% Recovery of Metoprolol Succinate and Benidipine Hydrochloride

\begin{tabular}{|l|l|c|c|c|c|}
\hline & $\begin{array}{l}\text { Conc. } \\
\text { Level (\%) }\end{array}$ & $\begin{array}{l}\text { Sample Amount } \\
(\boldsymbol{\mu g} / \mathbf{m l})\end{array}$ & $\begin{array}{l}\text { Amount Added } \\
(\boldsymbol{\mu g} / \mathbf{m l})\end{array}$ & $\begin{array}{l}\text { Amount recovered } \\
(\boldsymbol{\mu g} / \mathbf{m l})\end{array}$ & $\begin{array}{l}\text { \% } \\
\text { Recovery }\end{array}$ \\
\hline \multirow{2}{*}{$\begin{array}{l}\text { Benidipine } \\
\text { Hydrochloride }\end{array}$} & $80 \%$ & 4 & 3.2 & 3.229 & 100.89 \\
\cline { 2 - 6 } & $100 \%$ & 4 & 4 & 4.011 & 99.59 \\
\cline { 2 - 6 } & $120 \%$ & 4 & 4.8 & 4.577 & 99.105 \\
\hline \multirow{2}{*}{$\begin{array}{l}\text { Metoprolol } \\
\text { Succinate }\end{array}$} & $80 \%$ & 25 & 20 & 19.89 & 99.43 \\
\cline { 2 - 6 } & $100 \%$ & 25 & 25 & 24.09 & 99.39 \\
\cline { 2 - 6 } & $120 \%$ & 25 & 30 & 29.89 & 99.43 \\
\hline
\end{tabular}


Precision : Intraday Precision was found by analysis of standard drug at six times on the same day.While Interday Precision was carried out on six different day. The RSD was found to be less than 2 for both interday precision and intraday Precision. Result for the interday precision and intraday precision is shown in table II , III, IV ,V respectively.

Table II : Intraday Precision Data for estimation of Benidipine $\mathrm{HCl}$

\begin{tabular}{|c|c|c|c|}
\hline & \multicolumn{3}{|c|}{ Benidipine HCl } \\
\hline SR. NO. & $\begin{array}{c}\text { Conc. } \\
(\boldsymbol{\mu g} / \mathbf{m l})\end{array}$ & $\begin{array}{c}\text { Area } \\
\text { Mean } \pm \text { S.D. }(\mathbf{n}=3)\end{array}$ & \% R.S.D \\
\hline 1 & 4 & $911.282 \pm 7.622$ & 0.836 \\
\hline 2 & 8 & $1834.337 \pm 21.617$ & 1.178 \\
\hline 3 & 12 & $2573.720 \pm 25.122$ & 0.912 \\
\hline
\end{tabular}

Table III : Intraday Precision data for estimation of Metoprolol Succinate

\begin{tabular}{|c|c|c|c|}
\hline & \multicolumn{3}{|c|}{ Metoprolol Succinate } \\
\hline SR. NO. & $\begin{array}{c}\text { Conc. } \\
(\boldsymbol{\mu g} / \mathbf{m l})\end{array}$ & $\begin{array}{c}\text { Area } \\
\text { Mean } \pm \text { S.D. }(\mathbf{n}=3)\end{array}$ & \% R.S.D \\
\hline 1 & 25 & $1951.287 \pm 13.155$ & 0.674 \\
\hline 2 & 50 & $3936.533 \pm 25.460$ & 0.647 \\
\hline 3 & 75 & $5900.630 \pm 37.377$ & 0.633 \\
\hline
\end{tabular}

Table IV : Interday Precision data for estimation of Benidipine $\mathrm{HCl}$

\begin{tabular}{|c|c|c|c|}
\hline & \multicolumn{3}{|c|}{ Benidipine HCl } \\
\hline SR. NO. & $\begin{array}{c}\text { Conc. } \\
(\boldsymbol{\mu g} / \mathbf{m l})\end{array}$ & $\begin{array}{c}\text { Area } \\
\text { Mean } \pm \text { S.D. }(\mathbf{n}=3)\end{array}$ & \% R.S.D \\
\hline 1 & 4 & $908.023 \pm 10.533$ & 1.160 \\
\hline 2 & 8 & $1835.168 \pm 16.643$ & 0.907 \\
\hline 3 & 12 & $2754.057 \pm 16.371$ & 0.594 \\
\hline
\end{tabular}

Table V : Interday Precision data for estimation of Metoprolol Succinate

\begin{tabular}{|c|c|c|c|}
\hline & \multicolumn{3}{|c|}{ Metoprolol Succinate } \\
\hline SR. NO. & $\begin{array}{c}\text { Conc. } \\
(\boldsymbol{\mu g} / \mathbf{m l})\end{array}$ & $\begin{array}{c}\text { Area } \\
\text { Mean } \pm \text { S.D. }(\mathbf{n}=3)\end{array}$ & \% R.S.D \\
\hline 1 & 25 & $1948.001 \pm 13.549$ & 0.695 \\
\hline 2 & 50 & $3922.802 \pm 42.249$ & 1.077 \\
\hline 3 & 75 & $5900.556 \pm 21.806$ & 0.369 \\
\hline
\end{tabular}

LOD and LOQ : Limit of Detection and Limit of Quantitation are calculated based on calibration curve and the results are shown in table. VI

Table VI : Result oF LOD \& LOQ for Benidipine HCl \& Metoprolol Succinate

\begin{tabular}{|l|l|c|c|}
\hline S.N. & \multicolumn{1}{|c|}{ Name of Drug } & LOD & LOQ \\
\hline 1 & Metoprolol Succinate & $1.738 \mu \mathrm{g} / \mathrm{ml}$ & $5.266 \mu \mathrm{g} / \mathrm{ml}$ \\
\hline 2 & Benidipine $\mathrm{HCl}$ & $0.204 \mu \mathrm{g} / \mathrm{ml}$ & $0.618 \mu \mathrm{g} / \mathrm{ml}$ \\
\hline
\end{tabular}

Application of Proposed Method to the Pharmaceutical Dosage Form:

The Proposed method was applied successfully to the tablet dosage form and results obtained are shown in table VII .

Table VII : Result of analysis on marketed formulation

\begin{tabular}{|c|c|c|}
\hline Tablet & \multicolumn{2}{|c|}{ Benipack - M } \\
\hline Label claim & Benidipine HCl (4mg) & Metoprolol Succinate (50mg) \\
\hline Assay (\% of label claim) Mean \pm S. D. & $98.403 \pm 1.196$ & $101.828 \pm 0.700$ \\
\hline
\end{tabular}




\section{CONCLUSION:}

A simple rapid, precise and reliable method was developed for the estimation of the Benidipine $\mathrm{HCl}$ and Metoprolol Succinate in combined dosage forms. The results obtained are within the specified limit by the ICH guidelines. Analytical column used and the mobile phase provide good separation and gives the sharp results. The retention time observed for both the drugs was good hence the method can be used for routine analysis in quality control laboratories.

\section{REFERENCES:}

1) Tripathi KD.,Essentials of Medical Pharmacology. $5^{\text {th }}$ Edition Jaypee Brothers Medical Publishers (P) Ltd : New Delhi 110 002 , India, 2003, p. 503-514.

2) United States Pharmacopeia and National Formulary (USP 30NF 25). Vol 30 (3). Rockville, MD: United States Pharmacopeial Convention; Asian Edition, 2007 : 2647-2649.

3) Gold T, Shterman N. Metoprolol succinate extended release tablets and methods for their preparation. European Patents EP20060252598, 2007.

4) Qinghua Z, Bo C, Guangyu X, Huafeng D. Preparation method of benidipine hydrochloride. China's Patent CN 201310611167, 2015

5) Aqil M, Ali A, Ahad A, Sultana Y, Najmi AK, Saha N. A Validated HPLC Method For Estimation of Metoprolol in Human Plasma. Acta Chrom 2007; 19: 130-140

6) Phale MD, Hamrapurkar PD. .A Validated and Simplified RPHPLC of Metoprolol Succinate from Bulk Drugs. Asian Journal of Research in Chemistry 2009 ;2(2): 119-122

7) Chandana M, Rao MP, Ramya B, Sagar DV, Marsis DT, Gnana R, Anilkumar K, Haritha K .Quantification of Metoprolol Succinate in bulk and tablet formulation by HPLC: Method development and validation. European Journal Of Pharmacy and Reaserch 2016; 11(4): 31-40

8) Kalisetty S, Reddy TS, Reddy AM, Palnati JB, Rao DV, Manikandan R. Stability Indicating Reverse phase Liquid chromatographic Method for the Determination of Metoprolol succinate in Pharmaceutical dosage forms" Journal of chemistry and pharmaceutical Reasech., 2012; 4(9): 44204425

9) Kumar CH, Munnari S, Kuchana V, Kannappan N, Development and validation of a stability indicating RP-HPLC method for determination of Metoprolol Succinate in pharmaceutical dosage forms. Der Pharm. Sinica, 2014 ;5(6): 69-78

10) Shitole SV, Gurjar M, Shah M, Bal G, Pimple S, Patel R,. Stability Indicating RP-HPLC Method for Quantitative Estimation of S () Metoprolol Succinate in tablet dosage form. Americal Jornal of Pharmtech Research 2014; 4(5) : 712-721.

11) Saravanan G, Pamarthi NP, Jeneyellu IS, Visagaperumal D. Development And Validation of Stability Indicating RP-HPLC method for the simultaneous estimation of Metoprolol Succinate and Cilnidipine in bulk and pharmaceutical dosage form. International Journal of pharmaceutical sciences. 2014 ; 7(1): 150-154.

12) Madhukar A, Kannapan N,. RP-HPLC Method for the Simultaneous Estimation of Cilnidipine and Metoprolol Succinate in Bulk and tablet dosage form in Biorelevant Media (FaSSIF). International journal of pharmaceutical technology and reaserch. 2014-2015, 7(1), 172-184.

13) Kumar TH, Sankar DG, Stability Indicating RP-HPLC Method Development And Validation For Simultaneous estimation of Metoprolol Succinate and Cilnidipine in bulk and pharmaceutical formulation. Indo americal journal of pharmaceutical sciences., 2016 ; 6(4) : 5338-5350.

14) Godse VP, Bhosale AV, Bafana YS, Borkar DD, StabilityIndicating HPLC method for simultaneous determination of Metoprolol Succinate and Hydrochlorothiazide in combination drug products. International Journal of chemistry and sciences.2009; 7(3): 1733-1745.
15) Chitlange SS, Bhusal RD, Nikumbh MB, Bhole RP,. Development and validation of spectrophotometric and stability indicating RP-HPLC method for the simultaneous estimation of Metoprolol Succinate and Hydrochlorothiazide in tablet dosage form. International Journal of Pharmacy., 2012; 2(3): 591-597.

16) Chitlange SS, Imran M, Sakarkar DM, RP-HPLC method for simultaneous estimation of amlodipine and metoprolol in tablet formulation. Asian journal of Pharmacy , 2008;1 : 232234

17) Varma D, Rao AL, Dinda SC, Validated Stability Indicating HPLC method for simultaneous determination of Amlodipine and Metoprolol in bulk drug and pharmaceutical formulations. International journal of pharmacy and chemistry. 2012; 2(3) :876-884.

18) Shitole S, Gurjar M, Shah M, Pimple S, Bal G, Patel R. Development and validation of stability indicating RP-UPLC method for simultaneous determination of related substances of S (-) Amlodipine and S (-) Metoprolol succinate in fixed dose combination tablet dosage form. International Journal of pharmacy., 2009; 2(3):146-152.

19) Chandrabatala V, Ramkrishna K,.Gradient RP-HPLC Method for simultaneous estimation of Metoprolol, Ramipril and Atorvastatin in tablet dosage form. Rasayan Journal of Chemistry., 2015; 8(4): 404-410.

20) Shaikh KA, Patil AT, Stress degradation studies of Telmisartan and Metoprolol extended release tablets by a validated stability indicating reverse phase-high performance liquid chromatography method.Drug development and thearapeutics., 2014; 5(2): 158-163.

21) Yunooos M, Sankar DG, .Stability indicating reverse phase LC method development and validation for simultaneous estimation of metoprolol succinate and chlorthalidone in combined tablet dosage form. Der pharmaceutica 2015; 7(4): 162-172.

22) Bari SB, Patil MS, Validated and Stability indicating of RP-HPLC method for simultaneous estimation of S(-)Metoprolol Succinate \& Clopidogrel Bisulfate in bulk and tablet dosage form. International Journal of innovative research and development. 2013; 2(7): 484-489.

23) Thakker NM, Panchal HB, Rakholiya DR, Murugan R, Choudhry VP, Kuchekar BS, Development and validation of a stability indicating RP-HPLC method for simultaneous estimation of Olmesartan Medoxomil and Metoprolol Succinate in pharmaceutical dosage form. Pharmaceutical. Methods, 2012; 3(2) :84-89.

24) Hinge MA, Mahida RJ, Sojitra PS, Development and Validation of an RP-HPLC Method for Simultaneous determination of Trimetazidine Hydrochloride and Metoprolol Succinate. Internatioanl Journla of Chemistry and pharmaceutical analysis., 2015; 2(2): 77-83.

25) Singhvi I, Chaturvedi SC, Spectrophotometric method for estimation of Amlodipine Besylate and Benidipine Hydrochloride from Tablet, Indian journal of pharmaceutical sciences, 1999:190-191

26) Magara H, Kobayashi H, Kobayashi S. Determination of benidipine hydrochloride in human plasma by capillary column gas chromatography-negative ion chemical ionization mass spectrometry. Journal of Chromatography. B, 1993 ; 617(1): 59-63

27) Atici EB, Karliga B,. Identification, synthesis and characterization of process related impurities of benidipine hydrochloride, stress-testing/stability studies and HPLC/UPLC method validations Journal Of Pharmaceutical Analysis, 2015; 5:265-268

28) Willard HH, Merritt LL, Dean JA, Settle FA, Instrumental Methods of Analysis , 7th Edition CBS Publishers \& Distributors, New Delhi - 110002, India , 1988; 160 -178.

29) Proceedings of the International Conference on Harmonization (ICH), Q2B: Text on Validation of Analytical Procedures: Definitions and Terminology, USFDA Federal Register; 1995. 